\title{
Teoria poetyki Konstantego Troczyńskiego
}

\author{
Sylwia Panek
}

Sięgnięcie do archiwum polonistycznych teorii literaturoznawczych niesie za sobą przynajmniej dwa pożytki. Pierwszym jest wskazanie na teksty „założycielskie”, które przez siłę swojego oddziaływania, recepcję, a tym samym generowaną inspirację, budują, będąc ogniwem w łańcuchu, główną linię rozwoju polskiej teorii literatury. Drugim jest przypomnienie tekstów zapomnianych lub nigdy wystarczająco poznanych, a rewolucyjnie oryginalnych, śmiałych i twórczych, włączenie ich do świadomości i pamięci polonistycznej, a tym samym nadanie im rangi właściwej ich rzeczywistej wartości.

Takiego wprowadzenia w krąg szerszego zainteresowania wymaga z pewnością napisana w 1928 roku Teoria poetyki Konstantego Troczyńskiego - będąca niewydaną za życia jej autora w całości ${ }^{1}$ rozprawą doktorską (której promotorem był prof. Tadeusz Grabowski, a recenzentami profesorowie Florian Znaniecki i Michał Sobeski) 22-letniego zaledwie absolwenta dwóch kierunków Uniwersytetu Poznańskiego - socjologii (seminarium prof. Floriana Znanieckiego) i polonistyki (seminarium prof. Tadeusza Grabowskiego). Choć bowiem, jak pisał w monograficznym studium o życiu i twórczości poznańskiego literaturoznawcy Stanisław Dąbrowski w 1988 roku (a teza ta nie straciła wiele na aktualności) „Troczyński jest do przypomnienia wszystek”2, to Teoria poetyki Troczyńskiego jest konieczna „do przypomnienia” w szczególności.

Po pierwsze dlatego, że warto, by literaturoznawcy znający pozycje książkowe poznańskiego badacza, będące - dodajmy - efektem jego imponująco efektywnej pracy, owocującej pięcioma tomami literaturoznawczymi, które zostały napisane w ciągu zaledwie dziesięciu lat (Rozprawa o krytyce literackiej, 1931, Zagadnienia dynamiki poezji, 1934, Od formizmu do moralizmu, 1935, Elementy form literackich, 1936, Artysta i dzieło. Studium o Próchnie Wacława Berenta, 1938) poznali również źródło, czy też „jądro”, nieustannie rozwijanych przez niego i doprecyzowanych w tekstach późniejszych poglądów teoretycznoliterackich. By mogli, włączając Teorię poetyki

\footnotetext{
${ }^{1}$ Fragment rozprawy pt. Przedmiot i podział nauki o literaturze ukazał się w tomie 1919-1929. Księga Pamiątkowa wydana na dziesięciolecie istnienia Koła Polonistów Uniwersytetu Poznańskiego. Poznań 1930 (przedruk: Teoria badań literackich w Polsce. Wypisy, opr. H. Markiewicz, t. 2, Kraków 1960, s. 16-34).

${ }^{2}$ S. Dąbrowski, Konstanty Troczyński - człowiek i doktryna. Zbiór rozpraw, Wrocław 1988, s. 25.
} 
w krąg swojego zainteresowania twórczością Troczyńskiego, prześledzić zarówno ewolucję przekonań uczonego, jak i (jednak) stałość podstawowych intencji i celów literaturoznawcy wiernego wyjściowym założeniom samodzielnie wypracowanej u początku swojej naukowej drogi metodologii ${ }^{3}$.

Po drugie, przypomnienie Teorii poetyki wydaje się warte podjęcia dlatego, że należy uzupełnić obraz przełomu antypozytywistycznego w polskim literaturoznawstwie o pozycję z jednej strony symptomatyczną dla ruchów intelektualnych mających na celu wykształcenie podstaw metodologicznych nauk humanistycznych, z drugiej - sceptyczną wobec pochopnych (a nawet według Troczyńskiego - „mylnych”) wniosków wyciąganych przez niektórych twórców antypozytywistycznej metodologicznej rewolty. Troczyński swoim tekstem nie tyle „nie reagował na argumenty przełomu" ", ale właśnie na nie odpowiadał szybką i samodzielną reakcją krytyczną, wpisując się świadomie polemicznie wobec idiograficznych argumentów Badeńczyków i budując inną niż twórcy „humanistyki rozumiejącej”, formalistyczną, prefenomenologiczną i prestrukturalistyczną?) reakcję na potrzeby literaturoznawstwa początku XX wieku.

Po trzecie i najważniejsze wreszcie, warto przypomnieć Teorię poetyki Konstantego Troczyńskiego dlatego, że jest to po prostu pozycja wyjątkowa. Gdy Tadeusz Grabowski krytycznie w roku 1930 opisywał i oceniał stan badań poznańskiej polonistyki (pisząc o niedostatecznym zainteresowaniu „naukowym opisem utworów i systematyką twórczości literackiej, wreszcie badaniem zewnętrznego funkcjonalizmu dzieła, czyli nauką o formach i środkach literackich"5), musiał pamiętać, że chlubnym odstępstwem od tej reguły była obroniona rok wcześniej pod jego promotorskimi skrzydłami praca doktorska Troczyńskiego. Po latach widać rangę i innowacyjność tego tekstu w sposób szczególnie wyraźny. Maciej Gorczyński, umieszczając rozprawę Troczyńskiego na tle rozległej i wnikliwej panoramy rozwoju polskiej teorii literatury lat 1913-1918, wnioskuje jednoznacznie o jej nowatorskim charakterze, pisząc, że autor Teorii poetyki przedstawił „całościowy projekt wiedzy o literaturze o nieznanym wcześniej stopniu abstrakcji, nieodwołujący się do znanej potencjalnym czytelnikom tradycji teoretycznoliterackiej”, a „rozpoznanie nauki o literaturze, jej podziału, struktury, terminologii w wykonaniu Troczyńskiego (jako autora Teorii poetyki właśnie- S.P.) było absolutną nowością [wyróżnienie - S.P.]”.

Największą zasługę dla wprowadzenia do badań literaturoznawczych tego debiutanckiego tekstu poznańskiego badacza mają, oczywiście, kompetentni autorzy rzetelnie zredagowanych wydań krytycznych rozprawy Troczyńskiego - Stanisław Dąbrowski, którego staraniem po raz pierwszy w 1997 roku w całości (w ramach Pism wybranych Troczyńskiego) ukazała się

\footnotetext{
${ }^{3}$ Ciągłość myśli Troczyńskiego podkreślają: S. Dąbrowski, Od doktoratowego szkicu ku rozwiniętej doktrynie literaturoznawczej. Logika i dynamika drogi naukowej Konstantego Troczyńskiego, „Pamiętnik Literacki” 1991, z. 1; S. Wysłouch, Konstanty Troczyński - nonkonformista i nowator, wstęp do: K. Troczyński, Teoria poetyki i inne prace, wstęp i wybór tekstów S. Wysłouch, seria: Klasycy Nauki Poznańskiej, red. A. Pichan-Kijasowa, t. 57, Poznań 2011; Ł. Wróbel, Konstantego Troczyńskiego ujęcie literatury faktu, [w:] tegoż, Hylé i noesis, Toruń 2013; natomiast o linii rozwojowej Troczyńskiego, która jest „trudno czytelna, bo autor przedstawił ją w sposób skrótowy i skrajnie abstrakcyjny” pisze Henryk Markiewicz w swoim artykule Teoria literatury i badań literackich w latach 1918-1939, „Pamiętnik Literacki” 1979, z. 2.

${ }^{4}$ Por. K. Krassuski, Normy i formy. Konstanty Troczyński teoretyk i krytyk literatury, Wrocław 1982.

${ }^{5}$ T. Grabowski, Polonistyka Poznańska, [w:] 1919-1929. Księga Pamiq̨tkowa..., dz. cyt., s. 7.

${ }^{6}$ M. Gorczyński, Prace u podstaw. Polska teoria literatury 1913-1918, Wrocław 2009, s. 105.
} 
Teoria poetyki ${ }^{7}$ i Seweryna Wysłouch, która opracowując tom rozprawy Troczyńskiego zadecydowała o pouczającym zestawieniu tego tekstu z fragmentami późniejszych jego publikacji, pokazując (także we wnikliwym wstępie do dokonanego wyboru prac) kontynuację Teorii poetyki w kolejnych rozważaniach uczonego jako teoretyka poezji i komentatora tekstów literackich, stosującego w praktyce interpretacyjnej formalistyczne założenia wypracowanej samodzielnie metodologii ${ }^{8}$.

Punktem wyjścia rozważań Troczyńskiego jako autora Teorii poetyki jest świadomość funkcjonowania nauk humanistycznych w sytuacji kryzysu nauki o literaturze, będącego efektem chaosu w określeniu jej przedmiotu, różnorodności metod opisu i klasyfikacji literatury oraz braku jasnych i jednoznacznych pojęć (s. 35). Sytuacja ta zmusza zatem, wnioskuje badacz, zarówno do rewizji metodologicznych przesłanek, na których oparta jest dotychczasowa wiedza o literaturze, jak i do konstrukcji nowych założeń metodologicznych nauki, zgodnych z charakterem badanego przedmiotu.

Osobliwość odpowiedzi Troczyńskiego na kryzys nauk humanistycznych polega na tym, że jego projekt literaturoznawczy jest polemiczny zarówno wobec pozytywistycznego genetyzmu, jak i wobec postulatów inicjatorów przełomu antypozytywistycznego - twórców szkoły badeńskiej (Windelbanda i Rickera), postulujących rozróżnienie nauk humanistycznych i przyrodniczych w ramach opozycji języków nomotetycznego i idiograficznego.

Dla obrony własnego projektu teoretycznoliterackiego Troczyński obiera „świadomie jednoznaczne stanowisko" (s. 41). Rozumie bowiem swoje zadanie jako powinność zbudowania wywodu, którego celem podstawowym nie będzie pedantyczne dokonanie kompletnego przeglądu cudzych stanowisk (taką metodę nazywa „historyczną”) lub prowadzenie obrony własnych tez poprzez konsekwentne sytuowanie ich wobec racji oponentów (byłaby to metoda „polemiczna”), ale zaproponowanie (w ramach metody „konstruktywnej”) spójnego projektu nauki o literaturze, będącego odpowiedzią na jej kryzys i rozwiązującego nieprzezwyciężone dotąd w ramach odnotowywanych stanowisk dylematy i paradoksy. „Zadaniem więc niniejszej pracy jest rekonstrukcja filozoficznych podstaw poetyki, czyli określenie przedmiotu jej badań, rozwiązanie głównych metodyczno-poznawczych zagadnień poetyki, czyli określenie narzędzi i stanowisk metodycznych w opracowywaniu poznawczym faktów, następnie wskazanie podstawowych zagadnień poetyki, naszkicowanie metod ich rozwiązania, wreszcie określenie jej jako nauki, wyznaczenie jej stanowiska w zakresie refleksji naukowej w ogóle i refleksji naukowej nad literaturą w szczególności" (s. 41).

W opozycji do pozytywistycznego tainizmu zamierza zatem Troczyński współbudować przemiany w badaniach literackich, które „Na miejscu badania tekstu literackiego jako odrębnej sfery rzeczywistości istniejącej poza tekstem” stawiać będą „badanie tekstu, jako odrębnej sfery rze-

\footnotetext{
${ }^{7}$ K. Troczyński, Pisma wybrane, t. 1: Studia i szkice z nauki o literaturze, opr. S. Dąbrowski, Kraków 1997 (rękopis tekstu Troczyńskiego znajduje się w Archiwum Uniwersytetu im. Adama Mickiewicza w Poznaniu, rkps 208).

${ }^{8}$ K. Troczyński, Teoria poetyki..., dz. cyt., w ramach tej pozycji książkowej przedrukowano w tomie oprócz tekstu Teorii poetyki dwa fragmenty książki Troczyńskiego Od formizmu do moralizmu. Szkice literackie (Poznań 1935): Intymność i forma. W sprawie pojęcia czystej liryki i O istocie sztuki oraz fragment rozprawy Artysta i dzieło. Studium o „Próchnie” Wacława Berenta (Poznań 1938).
} 
czywistości ludzkiej, czyli dzieła sztuki”. Podstawowym zaś pojęciem tego badania czynić będą zatem „kształt, formę wyraz artystyczny, jako obiektywnie każdy tekst warunkujący” (s. 39).

Tekst literacki jest, w założeniu intencjonalnie przezwyciężanych przez Troczyńskiego metodologii, determinowany zróżnicowanymi elementami jego genezy, co badaczy te metodologie współtworzących motywuje do przyjęcia języków apologizujących owe determinizmy. W konsekwencji, w sposób - według poznańskiego badacza - nieuprawniony, badają oni teksty literackie jako efekty: a) determinacji psychologicznej (w ramach której „każde zjawisko literackie traktuje się jako wiarygodny, pewny obraz przeżycia i psychiki stwarzającego podmiotu", s. 50); b) determinacji filologicznej (tu: literatura jest traktowana jako „wytwór narodu”, a za cel jej badań uznaje się artykułowanie „historii uczuć i ideałów narodu” po to, by „określić indywidualny charakter psychiki narodu i jej strukturę") lub też c) determinacji historycznej, która łączy się zwykle z filologiczną, a traktuje literaturę jako „wyraz epoki”, sprowadzając ją do komentarza historii politycznej.

Wszystkie te nastawienia metodologiczne nakazują „,badanie tekstu jako źródła do poznania jakiejś rzeczywistości istniejącej poza tekstem, a której tekst jest wyrazem" (s. 56), gdy tymczasem zadaniem nowej, „czystej” - jak ją określa Troczyński - poetyki jest „badać tekst jako „odrębną sferę rzeczywistości” (s. 56), bowiem zajmuje ją „tekst literacki tylko jako dzieło sztuki, niezależnie od autora, środowiska społecznego i epoki historycznej" (s. 57). Jest to możliwe według poznańskiego badacza dopiero wtedy, gdy nauka o literaturze przyjmie założenie, iż przedmiot jej zainteresowania nie jest faktem wobec niej zewnętrznym (tu współbrzmi Troczyński i z Badeńczykami, i z Diltheyem), ale jest przedmiotem w ramach narzędzi, którymi dysponuje i które wypracuje ta nauka, wytworzonym, w istocie zatem - abstrakcyjnym, będącym efektem selekcji faktów (w tym miejscu poznański badacz odchodzi od wniosków „humanistyki rozumiejącej”).

O ile celem badań przezwyciężanych przez Troczyńskiego tendencji metodologicznych było - jak sam to ujmował - „fotografowanie rzeczywistości możliwie jak najwszechstronniejsze i jak najpełniejsze oddanie doświadczenia" (s. 57), o tyle, postulowane i ewidentnie oparte na inspiracjach konwencjonalistycznych nowe nastawienie literaturoznawcze, zakładając, że „świat nauki a świat konkretnego doświadczenia nie są do siebie w stosunku przedmiotu do kopii” (s. 57) i rozpoznając, że „w nauce tkwi także duża doza twórczości”, każe przejąć poetyce odpowiedzialność za literaturę, która w ramach absolutyzacji jej ambicji wypreparuje (z niej) własny przedmiot badań.

Rzeczywistość (jako zewnętrznie, obiektywnie istniejący nie-porządek) i nauka stoją bowiem, na gruncie najbardziej generalnych i podstawowych założeń przyjmowanych w tym projekcie teoretycznym, w kontrze. Jest tak dlatego, że postawa badacza/naukowca „drogą selekcji doboru i systematycznego porządkowania doświadczenia” odwołuje się do „czynności [które - S.P.] właśnie oddalają świat nauki od świata konkretności, czyli rzeczywistej obiektywnie istniejącej chaotyczności" (s. 58). Ale takie postawienie zagadnienia i przyjęcie owych założeń nie jest jedynie postępem w ramach wiedzy o literaturze, ale dopiero właściwym ustanowieniem badań literackich jako badań naukowych, bowiem „ideał wszechstronnego badania materiału i wyczerpania jego konkretnej zawartości nie tylko nie jest czymś wyższym poznawczo od jednostronnych nauk specjalnych, ale jest zasadniczo postulatem nienaukowym" (s. 58). 
Abstrakcyjność przedmiotu badań umożliwia i warunkuje dopiero naukowy charakter dyscypliny, co odwodzić będzie młodego badacza od akceptacji nastawień idiograficznych, które są „nieporozumieniem” (s. 67). Te bowiem, wysuwając pierwiastek indywidualny jako ostateczny cel poznania, konkretną całość utworu przeciwstawiając sztuczności wszelkich abstrakcyjnych podziałów i schematów, stawiając zarzuty wobec analizy, która niszczy jedność percepcji ${ }^{9}$, nie respektują faktu, że ujęcie pierwiastka indywidualnego możliwe jest jedynie dzięki uprzedniemu uchwyceniu cech dla danej klasy przedmiotów wspólnych, powtarzalnych, przeto i schematycznych. Cechy te natomiast można zidentyfikować jedynie poprzez (zwalczane w ramach idiografizmu) procedury systematyzacji i analitycznego porównania.

Zatem „zaryzykować można twierdzenie, że ujęcie idiograficzne niemożliwe jest bez uprzedniego, nomotetycznego [...] opracowania faktów” (s. 67) i w efekcie nie ma „dostatecznej racji”, by metody nieidiograficzne stosować jedynie w ramach badań rzeczywistości przyrodniczej. Dyscypliny przyrodnicze i humanistyczne są więc jedynie pozornie odmienne, bowiem w obu naukach „nasze postulaty poznawcze nie są dedukcyjnie z badanych faktów wyprowadzone, ale są implikowane i nie przesądzając istotnego charakteru badanej rzeczywistości, są tylko naszymi poznawczymi narzędziami w jej myślowym opracowaniu. W świecie przyrody także, obiektywnie biorąc, możliwa jest twórczość bezwzględna i indywidualna, jeżeli zaś o tym nic nie wiemy, to jedynie dlatego, że nasza wiedza przyrodnicza postulatywnie fakty te zanegowała" (s. 68-69).

Jedność metody naukowej wspólnej humanistyce i naukom przyrodniczym (jako poddanej tym samym generalnym dyrektywom i postulatom) jest w propozycji Troczyńskiego zbieżna z pozytywistyczną regułą „jedności metody wiedzy" ${ }^{10}$. Metoda ta jednak nie jest - jak w pozytywistycznej nauce - oparta na badaniu genezy zjawisk w celu ich opisu i wyjaśnienia oraz nie jest zdystansowana wobec włączania do nauki myślenia o wartościach. Wręcz przeciwnie - postulat humanistyki, która przemyślała zarówno doświadczenie pozytywizmu, jak i głównych argumentów Diltheya i Badeńczyków oparty został na wymogu wyabstrahowania zjawiska względem genezy, nadto jego oglądu z punktu widzenia wartości artystycznej.

Specyfikę nauce o literaturze nada więc nie nastawienie metodyczne, które byłoby generalnie odmienne od tego, jakie obowiązuje w naukach przyrodniczych, ale specyficznie osobliwy przedmiot badań w ramach tego nastawienia określony.

Ten przedmiot badań, w opinii autora Teorii poetyki, konstytuuje się poprzez poszukiwanie cechy głównej, podstawowej dla wyjściowego (traktowanego jako „materiał”) zjawiska z pominięciem jego cech wtórnych i „akcydensów” (s. 61). Tylko w taki sposób można bowiem uczynić zadość dążeniom delimitacyjnym nauk poszczególnych i odróżnić klasę tekstów literackich od tekstów innego rodzaju. Ta „postać” dzieła (jako jego „forma”, a nie jego „zawartość”, tj. „treść") jest zatem przedmiotem literaturoznawstwa jako nauki.

\footnotetext{
${ }^{9}$ Por. charakterystykę Troczyńskiego nastawienia idiograficznego na stronie 39 Teorii poetyki i krytykę tegoż nastawienia na stronach 65-68.

${ }^{10}$ Por. L. Kołakowski, Filozofia pozytywistyczna. Od Hume’a do Koła Wiedeńskiego, Warszawa 2004, s. 16-17.
} 
Czym natomiast jest tekst literacki w ujęciu Troczyńskiego? I czy on jako integralna całość pomieścić się może w badaniach literaturoznawczych?

Troczyński, uznając, że metoda badania tekstów literackich musi być formalna (a nie normatywna), za jej punkt wyjścia (adaptując inspiracje metodologiczne czerpane z Wstępu do socjologii Floriana Znanieckiego ${ }^{11}$ ) przyjmuje proces twórczy, tj. zjawisko czynności artystycznej, która tym się różni od czynności każdego innego rodzaju, że towarzyszy jej „świadomość stwarzania czegoś intencjonalnie fikcyjnego, nieistniejącego dotychczas i powoływanego do życia mocą kształtowania" (s. 62). Autonomiczność efektu czynności artystycznej i tym samym jego fikcyjność dokonuje się na drodze dwuetapowego procesu „obiektywizacji”. W ramach pierwszego jej etapu pisarz ustosunkowuje się do własnych stanów psychicznych jak do czegoś wobec własnej subiektywności obiektywnego, w ramach drugiego - daje już efektom tej operacji wyraz w materiale językowym.

W efekcie utwór literacki to „tekst zawierający świadomie komponowaną rzeczywistość, stanowiący nową «wsobną» rzeczywistość, czyli zawierający artystyczną fikcję" (s. 62); „tylko więc teksty zawierające świadomie tworzoną fikcję, czyli posiadające wartość artystyczną, stanowią materiał nauki o literaturze" (s. 63). Henryk Markiewicz ${ }^{12}$ stawia tezę, że to Troczyński po raz pierwszy w polskiej teorii literatury sformułował definicję eksponującą fikcję jako podstawową kategorię definiowania literatury.

Wyznacznikiem literackości jest zatem fikcja tworzona świadomie, będąca zarazem wartością artystyczną dzieła. Przedmiotem badania poetyki jest natomiast (dookreśla pedantycznie i konsekwentnie Troczyński, budując tym samym spójny i całościowy system zagadnień i pojęć składających się na tę naukę) „postać” tej fikcji, a nie jej „merytoryczna jakość”, bowiem - pisze stanowczo - „nauka literatury musi jednak zatrzymać się na płaszczyźnie formalnej, badając jedynie sztukę literacką jako postać i kształt nie wchodząc w merytoryczną interpretację", którą już pozostawić trzeba krytyce literackiej. Mówiąc dobitnie - poetykę interesuje dzieło literackie wyłącznie jako dzieło sztuki.

Fikcja literacka może być zatem ujmowana z trzech perspektyw: krytyki literackiej (wtedy, gdy dzieło literackie jest interpretowane np. jako wyraz psychologicznych uwarunkowań autora, projekt społeczny, źródło pomysłów filozoficznych itd. ${ }^{13}$ ) i nauki o literaturze (którą interesuje wyłącznie estetyczna postać dzieła literackiego) opartej na dwóch komponentach: teoretycznym (wówczas jest „morfologią poezji”, to: „nauka analityczna o elementach literackich ${ }^{14} \mathrm{i}$ ich typowych układach” - s. 70) i historycznym (badającym „dynamikę poezji” -tj. zmiany zachodzące w literaturze „drogą włączania ich w obiektywny przebieg rozwoju odpowiednich form literackich” - s. 106).

\footnotetext{
${ }^{11}$ Troczyński przyznaje się do tej inspiracji wprost we wstępie do rozprawy, por. Rozprawa jest próbq oparcia naukowej estetyki poezji na założeniach filozoficznych nauk humanistycznych Floriana Znanieckiego (K. Troczyński, Teoria poetyki..., dz. cyt., przypis 18, s. 42).

${ }^{12}$ H. Markiewicz, Główne problemy wiedzy o literaturze, Kraków 1996, s. 123 (por. na ten temat także S. Dąbrowski $Z$ zagadnień doktryny literaturoznawczej Konstantego Troczyńskiego, [w:] K. Troczyński, Pisma wybrane, t. 1: Studia i szkice z nauki o literaturze, oprac. S. Dąbrowski, Kraków 1997, przypis 19, s. 25).

${ }^{13}$ Por. K. Troczyński, Teoria poetyki..., dz. cyt., przypis 46, s. 63.

${ }^{14}$ Troczyński wymienia następujące „niezmienne” elementy dzieła literackiego: akcja, osnowa, symbol, porównanie (por. Teoria poetyki..., dz. cyt., s. 70).
} 
Spójną systematyzację podziału nauki o literaturze oraz - równocześnie - składników dzieła, które przez poszczególne gałęzie nauk są obejmowane, przedstawia badacz na przejrzystym wykresie:

\section{Dzieło literackie}
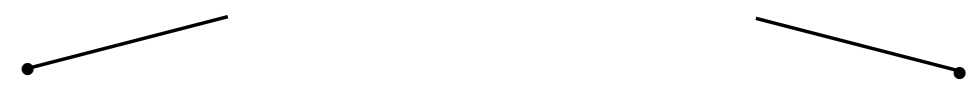

Postać (forma)

Zawartość (treść)

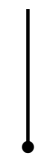

Struktura intencjonalna

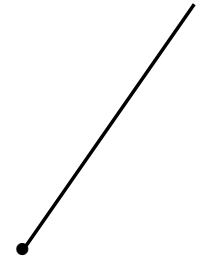

Zamiar artystyczny (postulowane efekty artystyczne)

c

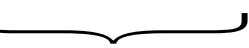

Struktura morfologiczna

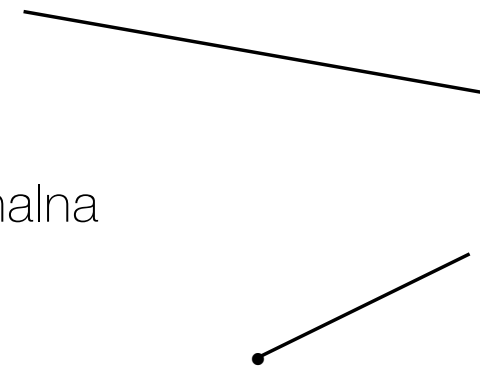

Fabuła

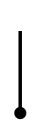

Kompozycja (zoobiektywizowane ponadpsychiczne przedstawienia)

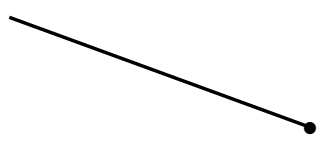

Technika

(sposoby przedstawiania

artystycznej wizji)

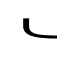

$\mathcal{L}$

Rodzaj literacki
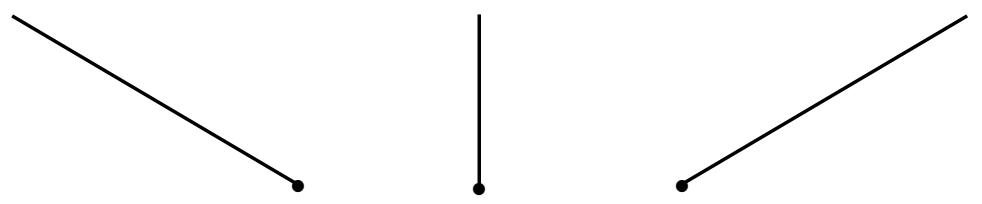

Morfologia poezji

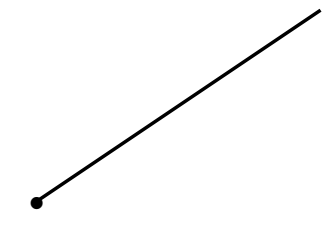

Poetyka
Faktura (słowne środki ekspresji wrażeń artystycznych)

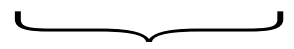

Styl literacki

Dynamika poezji

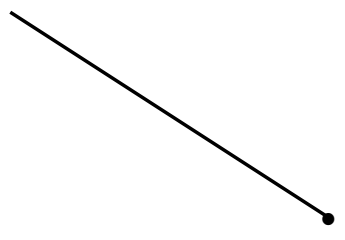


Jak widać na wykresie, poetyka, według Troczyńskiego, jest wyłącznie nauką o formie, tj. postaci dzieła literackiego, „eliminując zagadnienie treści, czyli zawartości jako pozaestetyczne i niedające się jako całość ująć teoretycznie" (s. 110). Zagadnieniami treści dzieł literackich zajmuje się - jak napisze autor Teorii poetyki w podsumowaniu swoich rozważań - „historia literatury [...] badając stosunek postaci do wyrażonej treści” (s. 110). Poetykę (rozumianą tu w znaczeniu szerokim - jako teorię literatury) sytuuje badacz tym samym obok historii literatury, bowiem są to dwie gałęzie literaturoznawstwa, które, jak słusznie zauważa, „wzajemnie się uzupełniają: teoria czerpie $\mathrm{z}$ historii literatury materiały i dane faktyczne, historia literatury z poetyki pojęcia, uogólnienia i prawa" (s. 110).

Forma stanowiąca przedmiot zainteresowania poetyki wymaga, według Troczyńskiego, zainteresowania zarówno układami dynamicznymi, jak i statycznymi. Według jego modelu poetyki jako nauki oznacza to zarówno konieczność badania zmiennych, odautorskich struktur intencjonalnych (które pozwalają identyfikować i opisywać kierunki literackie ${ }^{15}$ ), jak i - przede wszystkim - struktury morfologicznej, w ramach której identyfikować należy fabułę ${ }^{16}$ (fundamentalny element tekstu rozstrzygający o różnicy między wypowiedziami literackimi a innymi formami wypowiedzi) i fakturę (nie dość docenione przez Troczyńskiego ukształtowanie językowe testów literackich ${ }^{17}$ ). Fabuła jako fundament literatury jest zatem centrum tematycznym poetyki jako literaturoznawczej dyscypliny i ponadto podstawą wyróżniania gatunków literackich (o których swoistości decydują układy kompozycyjne składające się na fabułę) i rodzajów (opartych na identyfikowanych w tekście sposobach przedstawienia fikcji). Rodzaje i gatunki są zatem oparte na różnych kryteriach i krzyżując się, nie stanowią układu dwustopniowego. Poetyka jako nauka natomiast, badając w ramach wydzielanych problemów: rodzaje, gatunki, style literackie (pozostawione tu jednak - powtórzę - bez satysfakcjonującego nas zainteresowania badacza) i kierunki, obejmuje, będąc dziedziną systemową, kompletną sumę problemów implikowanych przez dzieło literackie jako dzieło sztuki.

Jakie warto wyprowadzić wnioski z przeprowadzonej dziś w trybie badań historycznych lektury tekstu z 1928 roku młodego poznańskiego badacza? Przede wszystkim warto przyznać, że tekst ten imponuje zarówno z powodu przyjętej i realizowanej przez autora metody, jak i z racji merytorycznej zawartości projektu.

Metoda prowadzenia wywodu uderza dwiema głównymi zaletami: po pierwsze - erudycja teoretyczno- i historycznoliteracka (odnotowywana głównie w przypisach do tekstu głównego) nie przesłania klarowności wywodu teoretyka, po drugie - realizacji postulatu nowatorstwa zgłaszanej propozycji literaturoznawczej (którą deklaruje autor wprost we wstępie rozprawy) dorównuje wnikliwość przeprowadzanych analiz. Zatem: erudycyjny rozmach i oryginalność propozycji teoretycznoliterackiej znajduje równowagę w jej klarowności i przenikliwości.

\footnotetext{
${ }^{15}$ „Kierunek literacki jest to więc system postulowanych, urzeczywistnianych i powtarzających się intencji artystyczno-literackich, w stosunku do struktury morfologicznej rodzajów, gatunków i stylów literackich" (s. 105).

${ }^{16}$ Fabułę definiuje Troczyński jako „zespół przedstawień (słów zawierających pewne umowne treści), tworzących artystyczną rzeczywistość”; można z niej wydzielić „części składowe: osnowę, akcję, epizody, charaktery, obrazy, opisy" (s. 81).

${ }^{17}$ O rozumieniu przez Troczyńskiego języka jako „łupiny” dla treści i pewnym dowartościowaniu języka (traktowanego jako wartość estetyczna) pisze dopiero w Elementach form literackich, por. S. Wysłouch, Konstanty Troczyński - nonkonformista i nowator, s. 22-23.
} 
Merytoryczną osobliwość Teorii poetyki natomiast jako teorii nauki trudno określić kilkoma słowami, wskazać jednak tu trzeba chociaż najważniejsze elementy, decydujące o wadze tego tekstu. Ostap Ortwin w 1923 roku pisał „Nie wyszliśmy jeszcze z przednaukowych powijaków gromadzenia faktycznych wiadomości o literaturze i katalogowania materiału poznawczego dla krytycznej morfologii i historii form i rodzajów, a prolegomena do przyszłej poetyki czy teorii literatury, która będzie mogła wystąpić jako nauka nie zaczęły się jeszcze wykluwać z mgławicy bardzo ryczałtowych ogólników"18. Teorię poetyki można (a nawet trzeba ${ }^{19}$ ) potraktować jako odpowiedź na wyrzut Ortwina. Odpowiedź dodajmy swoistą - „osobliwy wybłysk”20.

O szczególności tej odpowiedzi przesądza fakt, że autor tekstu, wyrastając z pytań przełomu antypozytywistycznego, nie przyjmuje ani patronatu Diltheya, ani de Saussure'a. W konsekwencji - co podkreśla Seweryna Wysłouch ${ }^{21}$ - w polskim literaturoznawstwie wyróżnia się oryginalnością zarówno wobec "generacji ojców” - przedstawicieli „humanistyki rozumiejącej" (takich jak Juliusz Kleiner i Zygmunt Łempicki), jak i wobec propozycji rówieśników, inspirujących się językoznawstwem strukturalnym (jak Franciszek Siedlecki, Kazimierz Budzyk, Stefan Żółkiewski).

Zapożyczenia i inspiracje (głównie ze Wstępu do socjologii Floriana Znanieckiego, ale także z tekstów Kazimierza Twardowskiego, Kazimierza Wóycickiego, Jana Łukasiewicza, Tadeusza Grabowskiego, Michała Sobeskiego, Stanisława Brzozowskiego, Williama Jamesa) są tu ściśle sfunkcjonalizowane i podporządkowane idei własnej, w myśl postulatu Znanieckiego, by „rozważać tylko te problemy, które postawiło się samemu"22. Tekst Teorii poetyki ponadto, który traktuje z całą mocą tekst literacki jako dzieło sztuki oparte na wartościach artystycznych, ujmuje go jako efekt intencjonalnych obiektywizacji odautorskich, definiuje wreszcie „obiektywność literatury” jako „obiektywność treści naszych doświadczeń literackich” (s. 72) powstał - pamiętać trzeba przed rokiem 1931, a zatem przed przełomowym Ingardenowskim Das literarische Kunstwerk!

Troczyński, gdyby szukać formacji literaturoznawczych, w które się swym projektem wpisuje, jest „formalistą” „W sensie występującego w historii estetyki formalistycznego paradygmatu sensu largo" ${ }^{23}$. Niedocenienie roli języka zdecydowanie różniło go od formalistów rosyjskich ${ }^{24}$, ale w wielu miejscach wnikliwością rozważań szczegółowych wyprzedza późniejsze dokonania strukturalizmu. Zarówno wtedy, gdy podnosi jako równoległy do synchronicznego - diachroniczny wymiar teoretycznego myślenia o tekście, jak i wówczas, gdy rozpoczynając swoje rozważania „formalne” (dotyczące dzieła literackiego od strony „czynności artystycznej”), neutralizuje w punkcie wyjścia niebezpieczeństwo immanentyzmu metody, wyprzedzając tym samym „niektóre ustalenia teorii komunikacji literackiej zwanej polskim komunikacjonizmem”25.

${ }^{18}$ O. Ortwin, Zagadnienie tragizmu w twórczości Wyspiańskiego, „Przegląd Warszawski” 1928, nr 25, s. 26.

${ }^{19}$ Znamienne, że słowa Ortwina cytuje sam Troczyński w swoim tekście Rozprawa o krytyce literackiej (por.

K. Troczyński, Rozprawa o krytyce literackiej, [w:] tegoż, Pisma wybrane, t. 1, s. 134 (przypis 21).

${ }^{20}$ S. Dąbrowski, Konstanty Troczyński..., dz. cyt., s. 47.

${ }^{21}$ Por. S. Wysłouch, Konstanty Troczyński - nonkonformista i nowator, s. 21.

${ }^{22}$ S. Dąbrowski, Z zagadnień doktryny..., dz. cyt., s. 48.

${ }^{23}$ M. Gorczyński, Prace u podstaw..., dz. cyt., s. 105; na temat prestrukturalizmu Troczyńskiego pisze A. JelecLegeżyńska w artykule Między formalizmem a strukturalizmem, „Nurt” 1976, nr 4.

${ }^{24}$ Por. S. Wysłouch, Konstanty Troczyński - nonkonformista i nowator, s. 23.

${ }^{25}$ Tamże, s. 24. 
Dziś znajdujemy także w teorii Troczyńskiego docenioną we współczesnej humanistyce kategorię „doświadczenia” czy też wykorzystanie przez niego pojęcie modalności, uruchomione dopiero niedawno w literaturoznawstwie ${ }^{26}$.

Kim jest Konstanty Troczyński jako autor Teorii poetyki? - zapytać można z dystansu, sięgając po latach do archiwum z jego debiutanckim tekstem.

Gdy Troczyński wypowiadał się o Karolu Irzykowskim jako o „poecie czwartego wymiaru”, pisał wnikliwie: „Z myśli ludzie zwykli robić sobie wygodny fotel do bujania. Irzykowski z pasją łamie nogi tym fotelom"27. Zaryzykuję tezę, że autor Teorii poetyki, charakteryzując tymi słowy postawę jednego ze swoich mistrzów, autorytet, który - jak dopowiadał z podziwem - „wyzwala myśl z obowiązku służenia od prawdy” ${ }^{28}$, zdradza się równocześnie ze swoim ideałem badacza/twórcy, któremu pragnie od najwcześniejszych lat, także Teoriq poetyki, sprostać. Wie, że prawem i siłą myślenia jest autonomia wobec faktów, a nie wobec faktów spolegliwość. I wie także, że (jednak) wyizolowanie poetyki od literatury, którego (co po latach widać wyraźnie) dokonuje swym odważnym projektem, jest skorzystaniem $\mathrm{z}$ tego prawa.

Zaprojektowane bowiem przez „czystą poetykę” czytanie tekstów literackich nie zbuduje nam odpowiedzi na pytania egzystencjalne, nie pomoże zrozumieć „ducha czasu”, nie zaproponuje interpretacji procesów społecznych. A jednak warto je uprawiać wbrew tym ograniczeniom, a raczej ze względu na nie.

Po co? Czy Troczyński chce być przekorny?

Na pewno, jako nonkonformista ${ }^{29}$ zawsze lubił przeciwstawiać się temu, co stało autorytarnie na straży powszechnie akceptowanych racji i wyjściowych gustów. Ale jest chyba i inna, osobna i ważniejsza, motywacja młodego polonisty, którą można wyrazić właśnie słowami cenionego przez niego Irzykowskiego. Obaj badacze/twórcy lubili bowiem „stany emocjonalne wytwarzające się na szczytach myślenia"30 i odczuwali je jako poezję. Teoria poetyki jako szczelna konstrukcja teoretyczna ma w sobie profil naukowej pedanterii i spójności, ale, dlatego właśnie, ma i profil artystycznej wizji, doprecyzowywanej potem przez lata w szczegółach także dla bezinteresownego ideału i perwersyjnego wzruszenia.

${ }^{26}$ Por. S. Wysłouch, Konstanty Troczyński - nonkonformista i nowator, s. 25.

${ }^{27}$ K. Troczyński, Poeta czwartego wymiaru. Rzecz o Karolu Irzykowskim, „Dziennik Poznański” 1935, nr 9, s. 3.

${ }^{28}$ Tamże.

${ }^{29}$ Postawie życiowej Troczyńskiego, por. K. Troczyński, Człowiek - postawa - los, [w:] S. Dąbrowski, Konstanty

Troczyński-człowiek i doktryna..., dz. cyt.; Cz. Latawiec, Spotkania z Konstantym Troczyńskim, „Nurt” 1976, nr 4;

S. Wysłouch, Konstanty Troczyński - nonkonformista i nowator.

${ }^{30}$ „Poezja to stan uczuciowy wytwarzający się na szczytach myślenia” - brzmi jeden z aforyzmów Irzykowskiego. 


\section{SEOWA KLUCZOWE:}

Konstanty Troczyński

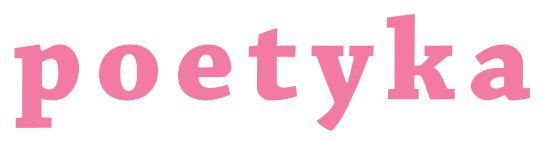

$$
\text { przełom }
$$

\footnotetext{
Abstrakt:

Artykuł jest omówieniem Teorii poetyki Konstantego Troczyńskiego - niewydanej za życia poznańskiego badacza debiutu książkowego, będącego podstawą jego doktoratu. Autorka, przedstawiając kompletną propozycję Troczyńskiego jako nauki, pokazuje ją jako oryginalną odpowiedź na wyzwania przełomu antypozytywistycznego, polemiczną zarówno wobec tainizmu, jak i reakcji na pozytywizm formułowanych w ramach „humanistyki rozumiejącej" (szkoła badeńska i Dilthey).
} 


\section{formalizm}

antypozytywistyczny

NOTA O AUTORZE:

Sylwia Panek - dr, adiunkt w Zakładzie Antropologii na Uniwersytecie im. Adama Mickiewicza w Poznaniu. Autorka książki Krytyk w przestrzeniach literatury i filozofii. O wypowiedziach polemicznych Karola Irzykowskiego (Poznań 2006), inicjatorka i redaktorka naukowa serii „Polemika Krytycznoliteracka w Polsce" (Wydawnictwo Poznańskiego Towarzystwa Przyjaciół Nauk). 